\title{
The Promise and Failure of King Amanullah's Modernisation Program in Afghanistan
}

\author{
Andrew Chua
}

\section{Abstract}

Nearly a century before the United States embarked on the perilous task of transforming Afghanistan into a modern nation state, King Amanullah dreamed of his country joining the ranks of modern states and embarked on a wide-ranging modernisation program. For ten years no area in society was left untouched by Amanullah's reforms; which, had they succeeded, would have transformed Afghanistan into a modern and westernised nation state. By 1929, however, the self-described revolutionary had been forced into exile, never to return to his beloved country, and his reforms were abrogated. This paper examines the policies and objectives of Amanullah's modernisation program. It argues that Amanullah mismanaged the reform process to the point of alienating almost every group in society. This led to a tribal revolt that brought an end to both Amanullah's reign and his modernisation program.

\section{Introduction}

More than ten years after invading Afghanistan to defeat the Taliban and establish a modern nation state, the United States finds itself unable to achieve those objectives and it has had only limited success in the Afghan nation-building effort. ${ }^{1}$ The current situation in Afghanistan mirrors another episode in the nation's past - the modernisation program of King Amanullah who, over a century earlier, sought to transform a rural and tribal society into a modern nation state from the top down during his decade-long reign from 1919 to 1929. Like the United States in post-2001 Afghanistan, Amanullah had a Western-centric approach to modernity, envisioning a state where the material and immaterial aspects of Western society and governance could coexist with

1 Vanda Felbab-Brown, Afghanistan Ten Years after 9/11: Counterterrorism Accomplishments while a Civil War Is Lurking? Brookings Institute (2011). http://www.brookings.edu/research/opinions/2011/09/06afghanistan-felbabbrown (accessed 1 October 2012). 
Islam. ${ }^{2}$ A rebellion in Khost in 1924 and a tribal revolt in 1929, however, resulted in Amanullah's self-exile in Italy until his death in 1960, and the dismantling of the modernisation program. ${ }^{3}$

This paper argues that Amanullah's objective of transforming Afghanistan into a modern nation state through reforms that would centralise authority, unify a fractured society and industrialise the economy, was not only promising, but also achievable. Amanullah mismanaged the implementation of his reforms, however, and alienated most segments of the population. Without an effective bureaucracy to convey and implement his modernisation program, few Afghans understood or benefited from his reforms. Nevertheless, most bore the burden of increased taxation to pay for them. Amanullah also antagonised tribal and religious leaders by curbing their power and prerogatives without ensuring that their interests were protected. Finally, the reforms, which were intended to strengthen the army, effectively crippled and alienated it, leaving Amanullah vulnerable to the widespread resentment that he had inadvertently generated.

\section{The Road to Modernisation}

Although modernisation only took centre stage after Amanullah's ascension to the throne, its seeds had been planted decades earlier during the reign of Habibullah Khan, Amanullah's father and predecessor who ruled from 1901 to 1919. Departing from the repressive rule from 1800 to 1901 of his own father, Abdur Rahman, the 'Iron Amir', Habibullah ushered in a progressive era in Afghanistan through the introduction of reforms, albeit on a limited scale. New roads, factories and Afghanistan's first hospital and hydro-electric plant were constructed. ${ }^{4}$ Habibullah did not stop at economic reforms, but also established Afghanistan's first school with a European-style curriculum in 1904, the Habibia College. Furthermore, he allowed the return of political exiles. ${ }^{5}$ The most prominent of the returning exiles was Mahmoud Tarzi who, during a period abroad, had been influenced by the reformist ideas of the Young Turk movement. On his return, Tarzi established the newspaper, Siraj al-Akhbar, to promote his vision of 'Muslim modernisation' - that is, a return to the days of the Abbasid Caliphate, where Islam could coexist with a modern and progressive society. ${ }^{6}$

\footnotetext{
2 Asta Olesen, Islam and Politics in Afghanistan (Richmond: Curzon Press, 1995), 118.

3 Amin Saikal, Modern Afghanistan, A History of Struggle and Survival (London and New York: IB Tauris, 2004), 73-92.

4 Martin Ewans, Afghanistan: A Short History of its People and Politics (New York: HarperCollins, 2002$), 85$.

5 Jeffery J Roberts, The Origins of Conflict in Afghanistan (Westport, CT; London: Praeger, date?), 37.

6 Vartan Gregorian, 'Mahmud Tarzi and Saraj-ol-Akhbar: Ideology of Nationalism and Modernization in Afghanistan', Middle East Journal 21, No. 3 (1967), 347.
} 
The new Afghan intelligentsia, formed from students of the Habibia College, drew inspiration from Tarzi's ideas about Afghan nationalism and modernisation, and by 1909, a reformist movement called the Young Afghans, or mashruta khwahan (constitutionalists), had emerged. ${ }^{7}$ Prince Amanullah was involved with the Young Afghans from the beginning. He grew particularly close to Tarzi, not only sharing his vision for Afghanistan's future, but even marrying one of Tarzi's daughters, the future Queen Soraya. ${ }^{8}$ Amanullah had long been troubled by the state of his country and, even as a child, he was 'deeply ashamed' of Afghanistan's backwardness. ${ }^{9}$ With the death of Habibullah in 1919, Amanullah had his chance to rectify this and, with Tarzi as his advisor and foreign minister, he publicly declared that Afghanistan would 'take its proper place among the civilised powers of the world'. ${ }^{10}$

\section{Centralisation of Authority and Administration}

The one objective that no Afghan ruler had truly achieved was unification of the country under a central government, and the establishment of a modern nation state. Thomas Barfield notes that the authority of the central government only applied in its full extent within urban areas, as rural areas remained largely autonomous. ${ }^{11}$ The fragile nature of the state ensured that temporary centralisation and unification were dependent on a strong leader, and his death would result in civil war until the next strong leader emerged. ${ }^{12}$ Amanullah, however, had an opportunity to break this cycle in 1919 when he waged the Third Anglo-Afghan War and secured Afghanistan's independence from Britain. ${ }^{13}$ With the significant political capital he gained from this success, Amanullah set out to achieve what his predecessors had failed to do, and forge Afghanistan into a modern nation.

In order to centralise administrative functions and political authority, a cabinet and legislature were established for the first time in Afghan history to assist the monarch in governing. ${ }^{14}$ In 1923 a de facto constitution, the Basic Codes of the

\footnotetext{
7 Saikal, Modern Afghanistan, 48.

8 ibid.

9 Leon B Poullada, Reform and Rebellion in Afghanistan, 1919-1929 (Ithaca and London: Cornell University Press, 1973), 39.

10 Hafizullah Emadi, Repression, Resistance and Women in Afghanistan (Westport CT: Praeger, 2002$), 60$.

11 Barfield calls this the 'Swiss cheese model', where leaders 'do not assume uniformity across the country or their control of it'. See Thomas Barfield, Afghanistan: A Cultural and Political History (Princeton, NJ: Princeton University Press, 2010), 67-70.

12 Dupree calls this the process of 'fusion and fission'. See Louis Dupree, 'Afghanistan, 1880-1973', in Commoners, Climbers and Notables, ed. CAO Nieuwenhuijze (Leiden: EJ Brill, 1977), 153.

13 Saikal, Modern Afghanistan, 61.

14 According to Max Weber, the centralisation of administrative functions and authority is essential in the transition to a nation state. See Max Weber, "Politics as a Vocation," in Max Weber: Essays in Sociology, ed. H.H. Gerth, 77-128 (London: Routledge, 1948), 82; Saikal, Modern Afghanistan, 73.
} 
High State of Afghanistan, was drafted with the assistance of Turkish experts and introduced several new concepts to Afghanistan, such as the freedoms of religion, speech and the press. ${ }^{15}$ The codes also established the rule of law and the concept of a constitutional monarchy, whereby the legitimacy of the king no longer rested on Islam, but on popular legitimacy. ${ }^{16}$ Amanullah also made judicial reforms, including the introduction of new laws based on secular Turkish legal codes, and the codification of sharia law, which would be exercised by a new system of secular courts. ${ }^{17}$ Ultimately, the political and legal reforms were intended to transfer power from the religious establishment (ulema), which had great influence due to its ability to interpret the sharia, to the monarchy and the central government.

Amanullah also sought to bring education under the control of the central government. He believed that the 'ignorance' of the Afghan people was responsible for the backwardness of the country. Educational reform was, therefore, 'closest to [his] heart' ${ }^{18}$ Prior to 1920 education was controlled by the ulema and largely involved rote learning sacred texts and classical works. The national literacy rate was barely two per cent. ${ }^{19}$ A secular curriculum was introduced alongside Islamic subjects, and new schools were established to provide vocational training. ${ }^{20}$ Compulsory education was also introduced in 1924 and, while due to a lack of resources it was not applicable to the entire country, Amanullah did attempt to make more options available. ${ }^{21}$ For instance, new primary and secondary schools were built and night literacy classes were opened for adult learners, at which the King himself occasionally taught. ${ }^{22}$ To emphasise the importance of education, Amanullah made the Medal of Education the highest decoration in the country. ${ }^{23}$

A centralised nation state also required an army that was loyal to the central government. The army of Amanullah's predecessors, however, consisted of soldiers nominated by the leadership of the tribes, and they retained their respective tribal loyalties. ${ }^{24}$ Moreover, the army proved to be incapable of defending the nation against foreign threats, as was evident in the near loss to the British during the Third Anglo-Afghan War. Afghanistan may have

\footnotetext{
15 The Basic Codes of the High State of Afghanistan (Nizam-Namah-ye Asasi-ye Aliyah-ye Afghanistan) avoided any reference to the term 'constitution' to allay fears that it would supplant the sharia. See Poullada, Reform and Rebellion, 93.

16 Olesen, Islam and Politics, 121.

17 Saikal, Modern Afghanistan, 74.

18 Poullada, Reform and Rebellion, 39; Olesen, Islam and Politics, 128.

19 Poullada, Reform and Rebellion, 86; Paul Overby, Amanullah: The Hard Case of Reform in Afghanistan, Occasional Paper 31 (New York: The Afghanistan Forum, 1992), 13.

20 Poullada, Reform and Rebellion, 88.

21 ibid., 89.

22 Saikal, Modern Afghanistan, 75.

23 ND Ahmad, The Survival of Afghanistan, 1747-1979 (Lahore: Institute of Islamic Culture, 1990), 187.

24 Poullada, Reform and Rebellion, 115.
} 
been defeated without the assistance of the Wazir and Mahsud tribes. ${ }^{25}$ In an attempt to rectify this, Amanullah followed the proposals of Tarzi and Turkish military advisors to create a professional army consisting of men from the entire population who were loyal to the central government instead of the tribes. ${ }^{26}$ Universal conscription was introduced for all men of the age of 21 for a period of two years; this was later extended to three years. ${ }^{27}$ As most of the soldiers in the army were veterans and resistant to change, Amanullah reduced their pay fourfold, to just four rupees a month, in order to force older soldiers out of the army. ${ }^{28}$ To compensate for the lower pay, soldiers were to be given a package of benefits, such as cooked food and uniforms. ${ }^{29}$ Inspired by the British use of air power during the Third Anglo-Afghan War, Amanullah also established an air force with assistance from the Soviets, who provided 13 airplanes as well as pilot training. ${ }^{30}$

\section{Unification of Society}

The nation state that Amanullah envisioned could not be achieved by centralising power and authority alone. It also required the unification of the 'multi-ethnic, multi-lingual and multi-religious society' that had only been temporarily unified in the past through the use of force. ${ }^{31}$ Amanullah sought to break down social divisions by abolishing slavery and child labour. ${ }^{32}$ Religious freedom was also granted to minority communities, who were encouraged to play an active role in the state. For instance, Amanullah admitted Sikhs and Hindus to military schools to train as army commanders, offering these communities an opportunity for social advancement. ${ }^{33}$ Amanullah also encouraged Western dress in place of traditional outfits, in the hope of making societal divides less visible. ${ }^{34}$

The most significant and controversial aspect of the social reforms was Amanullah's move towards the emancipation of women. For the first time in

\footnotetext{
25 ibid., 111.

26 ibid., 114.

27 Saikal, Modern Afghanistan, 78.

28 ibid.

29 Poullada, Reform and Rebellion, 117.

30 Peter Tomsen, The Wars of Afghanistan (New York: Public Affairs, 2011), 71; Sally Ann Baynard, 'Historical Setting', in Afghanistan, A Country Study, eds Richard F Nyrop and Donald M Seekins (Washington, DC Foreign Area Studies, The American University, 1986), 43.

31 Aqab M Malik, The Modernisation Process in Afghanistan - A Retrospective (Islamabad: Institute of Security Studies Islamabad, 2012), 39.

32 Ahmad, Survival of Afghanistan, 183-84.

33 Emadi, Repression, Resistance and Women, 60.

34 Poullada, Reform and Rebellion, 81. There was also a religious aspect to the clothing reforms. During a speech in Egypt, Amanullah chastised the Egyptians for treating the fez as a requirement of Islam and noted that he abolished traditional clothing in Afghanistan because it had 'no religious character'. See Ahmad, Survival of Afghanistan, 185.
} 
Afghan history, and in most parts of the Islamic world, women were granted freedom of choice in marriage, equal rights to inheritance, a minimum age for marriage and legal protection against abuse. ${ }^{35}$ Queen Soraya was a key figure in this emancipation process, and she publicly advocated for change in the roles of women as well as women's rights to education, employment and divorce. ${ }^{36}$ The first primary school for girls was opened in 1921, yet another first in Afghan history. ${ }^{37}$ To avoid these reforms being viewed as a covert bid at secularisation, great efforts were made to justify them in Islamic terms. For instance, Amanullah argued that monogamy was inherently more Islamic when he tried to discourage the practice of polygamy. ${ }^{38}$ Women were also encouraged to unveil and the veil was portrayed as a 'tribal custom' rather than a requirement of Islam. ${ }^{39}$ In a public speech, Queen Soraya argued that the reforms were intended to allow Afghan women to contribute to society 'in the manner of the women of early Islam' ${ }^{40}$

\section{The Seeds of Industralisation}

Amanullah's grand scheme for modernisation required vast sums of money, but foreign aid was no longer a viable option after the Third Anglo-Afghan War. Not only had the British not rescinded their annual financial subsidy but they also dissuaded other world powers from aiding Amanullah. ${ }^{41}$ The Soviets promised Amanullah technical and financial assistance to compensate for the British subsidy, but these promises were left largely unfulfilled. ${ }^{42}$ To make Afghanistan economically independent, Amanullah introduced economic reforms, which were intended to begin the process of industrialisation. ${ }^{43}$ He began by reorganising and rationalising the tax system, including the abolition of arbitrary taxes, such as those collected for 'oil for the queen's hair' ${ }^{44}$ He also introduced the first national budget in the history of Afghanistan and the afghani, a new currency, which replaced the largely valueless rupee. ${ }^{45}$ In order to finance industrialisation

35 Saikal, Modern Afghanistan, 75; Emadi, Repression, Resistance and Women, 62.

36 Shireen Khan Burki, 'The Politics of Zan from Amanullah to Karzai', in Land of the Unconquerable: The Lives of Contemporary Afghan Women, eds. Jennifer Heath and Ashraf Zahedi (Berkeley and Los Angeles: University of California Press, 2011), 46.

37 ibid.

38 Saikal, Modern Afghanistan, 75.

39 Ahmad, Survival of Afghanistan, 184.

40 Emadi, Repression, Resistance and Women, 63.

41 Saikal, Modern Afghanistan, 63-65.

42 The Soviets quickly lost interest in Afghanistan with the diminishing British presence in the country. See Roberts, The Origins of Conflict, 42.

43 Poullada, Reform and Rebellion, 137.

44 Saikal, Modern Afghanistan, 74; Poullada, Reform and Rebellion, 131.

45 Saikal, Modern Afghanistan, 74. 
Amanullah set out to improve agricultural productivity. This was achieved through a policy of land reform, where public land was sold to poor peasants at the low price of ten afghanis per jerib (0.5 acres) of irrigated land. ${ }^{46}$

Amanullah also began planning for the infrastructure requirements of an industrialised economy, with the construction of communication networks such as roads, telegraphic and telephone lines and postal services. ${ }^{47}$ The centrepiece of the infrastructure development was the Great North Road, which would finally provide a direct connection between northern and southern Afghanistan through the Hindu Kush. ${ }^{48}$ By the late 1920s, Afghanistan was also connected by air to Tashkent, Tehran and India. ${ }^{49}$ Amanullah purchased equipment to establish a light industrial sector, including industries such as woodworking, textiles and papermaking. ${ }^{50}$ Students were sent abroad to work as apprentices in European and Persian factories and to gain technical skills, which would be used to develop new industries in Afghanistan. ${ }^{51}$

\section{Alienating the Populace}

Amanullah's modernisation program was so comprehensive that it would have been difficult to implement even in a centralised nation state, much less a largely rural and decentralised Afghanistan. In order for reforms to be implemented throughout the country, a centralised bureaucracy, like the ones that Ataturk in Turkey and Reza Shah in Iran relied on for their own modernisation programs, was imperative. ${ }^{52}$ Amanullah, however, had neither the acumen nor the patience to develop such a capability before advancing with his reform agenda. Lacking political experience, Amanullah's modernisation plan was based entirely on theory that he 'learnt through books'. ${ }^{53}$ Furthermore, he allowed his embarrassment at Afghanistan's backwardness to cloud his judgment, turning a long-term reform process into a rushed scramble to show the world that 'Afghanistan exists on the map'.$^{54}$ Of the 76 decrees issued by Amanullah throughout his reign, covering every aspect of the modernisation program, 57

\footnotetext{
46 ibid., 75; Poullada, Reform and Rebellion, 135.

47 Saikal, Modern Afghanistan, 74.

48 Poullada, Reform and Rebellion, 141

49 Vartan Gregorian, The Emergence of Modern Afghanistan (Stanford: Stanford University Press, 1969$), 247$.

50 Poullada, Reform and Rebellion, 139-40.

51 ibid., 88-89.

52 Angelo Rasanayagam, Afghanistan: A Modern History (London: IB Tauris, 2003), 21.

53 Amanullah considered his European tour to be a way to 'complete [his] studies by personal observation and experience', while the furthest extent of his modernisation plan had been based on theory. See Gregorian, Emergence of Modern Afghanistan, 256.

54 M Nazif Shahrani, 'King Aman-Allah of Afghanistan's Failed Nation-building Project and its Aftermath', Iranian Studies 38, No. 4 (2005), 662.
} 
were issued before the Khost Rebellion in $1924 .{ }^{55}$ Had Amanullah heeded his predecessor Abdur Rahman's warning that reforms should not be introduced 'in such a hurry as to set the people against their ruler', the revolt in $1929 \mathrm{might}$ have been averted. ${ }^{56}$

In his rush to reform Afghanistan, Amanullah did not consider how his measures, especially the ones intended to benefit the people, would be implemented. In reality, most of Amanullah's reforms had little effect beyond areas under direct control of the central government. ${ }^{57}$ For instance, the abolition of slavery and forced labour was in all likelihood ignored outside of Kabul and the neighbouring provinces. ${ }^{58}$ Amanullah's strict laws to curb extortion by local officials were never enforced and corruption continued to flourish. ${ }^{59}$ By 1928, Amanullah was practically pleading with Afghans to cooperate with his modernisation program, lamenting that 'he advises you, implores you and presses you, but beyond that he can do nothing'. ${ }^{60}$

The lack of an effective bureaucracy also meant that Amanullah had no means of communicating directly with the vast majority of Afghans about the intention and scope of his reforms. With most news on the modernisation program reaching ordinary Afghans in the form of rumours, dangerous misunderstandings ensued. For instance, Pashtuns, who adhered to a strict tribal code (Pashtunwali) that viewed women as property to be 'protected', were horrified by supposed government bans on the veiling of women, when no such policy existed. ${ }^{61}$ When Amanullah planned to replace turbans with hats, because the former required a greater amount of imported cloth, conservative Muslims feared that it was an insidious anti-Islamic ploy to prevent them from pressing their foreheads to the ground during prayers. ${ }^{62}$ While conservative and rural Afghans would have found many of Amanullah's reforms unpalatable, the circulation of rumours and exaggerations intensified the distrust and hostility towards Amanullah and his program.

Although most of Amanullah's reforms generated little benefit for Afghans living outside urban areas, these ordinary Afghans were saddled with the financial costs. ${ }^{63}$ In his desire to make Afghanistan appear modern as soon as possible, Amanullah authorised costly projects, such as the new capital

55 ibid., 668.

56 Christopher D Dessaso, Toward Development of Afghanistan National Stability: Analyses in Historical, Military and Cultural Contexts (Kansas: School of Advanced Military Studies, United States Army Command and General Staff College, 2010), 23.

57 Saikal, Modern Afghanistan, 80.

58 Overby, Hard Case of Reform, 19; Poullada, Reform and Rebellion, 144-45.

59 Roberts, The Origins of Conflict, 45.

60 Ahmad, Survival of Afghanistan, 207.

61 Barfield, Cultural and Political History, 185; Overby, Hard Case of Reform, 19.

62 Poullada, Reform and Rebellion, 139.

63 Gregorian, Emergence of Modern Afghanistan, 270. 
Dar-ul-Aman, which cost ten million rupees, one third of the state's annual income. ${ }^{64}$ Leon Poullada lauds Amanullah's 'remarkable feat' in domestically funding the entire modernisation program with little foreign assistance. ${ }^{65}$ In reality, this was achieved through a significant increase in taxation. Over the ten-year period of Amanullah's reign, the land tax increased fourfold, while livestock tax increased two to fivefold. ${ }^{66}$ Ultimately, the primary effect that Amanullah's reforms had on ordinary Afghans was a heavier tax burden. Not surprisingly, as the Soviet Central Asian newspaper, Pravda Vostoka, noted at the time, this generated such resentment among the peasantry that they later supported the tribal and religious rebellion. ${ }^{67} \mathrm{In}$ fact, it was an attack on Amanullah's tax collectors by Shinwari tribesmen that set off the 1929 revolt. ${ }^{68}$

\section{Alienating Traditional Power}

Amanullah's reform program not only cost him popularity among the people, it also gained him powerful enemies among tribal leaders and the ulema, the traditional centres of power in Afghanistan who stood to lose most from Amanullah's plan for a centralised nation state. As Wolfgang Zapf notes, modernisation is 'not a consensual process, but a competition between modernisers, conservatives and bystanders', and Amanullah ended up on the losing side. ${ }^{69}$ Previous rulers were fully aware of the power commanded by the traditional forces in the country and either coopted them with financial subsidies and power-sharing, or controlled them through ruthless suppression. ${ }^{70}$ Amanullah did neither as he rapidly expanded his own power through his reforms. This made a revolt inevitable.

With the central government assuming responsibility for tasks that had previously been performed at a local level, such as conscription and taxation, tribal leaders found themselves losing power and opportunities for corruption. ${ }^{71}$ In Amanullah's drive to prioritise spending, he cut the subsidies to the tribes

\footnotetext{
64 Barfield, Cultural and Political History, 183; The new capital included personal comforts such as a racetrack, a movie theatre and a garage for Amanullah's car. See Tomsen, The Wars of Afghanistan, 73.

65 Poullada, Reform and Rebellion, 136.

66 Asger Christensen, Aiding Afghanistan: The Background and Prospects for Reconstruction in a Fragmented Society (Copenhagen: NIAS Publishing, 1995), 19.

67 Gregorian, Emergence of Modern Afghanistan, 270.

68 ibid., 264.

69 Wolfgang Zapf, Modernization Theory - And the Non-western World (Emeriti Projekte: Wissenschaftszentrum Berlin für Sozialforschung, 2004), 4.

70 Abdul Rahman waged numerous wars against rebellious tribes over his 20-year reign, with mass enslavement and executions as punishment. On the other hand, Habibullah made significant concessions to the tribal chiefs and allowed them to influence policy-making in order to improve relations. See Rasanayagam, A Modern History, 11-15.

71 Barfield, Cultural and Political History, 184.
} 
that previous rulers had instituted. ${ }^{72}$ Moreover, it was not only the purses of the tribal chiefs that were attacked, but also their pride. Traditional ranks and titles were abolished in the spirit of egalitarianism and tribal chiefs were targeted by Amanullah's anti-corruption drive, which even resulted in the imprisonment of his relative, the Durrani tribal chief Sarwar Khan. ${ }^{73}$ This was considered a gross violation of tribal notions of kinship and loyalty.

The relationship between monarch and ulema had long been a contentious one and Amanullah's inability to recognise the potential threat posed by the ulema to his reign and reforms proved to be his undoing. Although Amanullah began his reign with a considerable amount of goodwill among the ulema his victory against the British, this quickly eroded due to his foreign policy outreach towards Turkey and Iran, which were viewed as anti-Islam due to their secularisation programs, and the atheist Soviet Union. ${ }^{74}$ Like the tribal chiefs, the ulema detested Amanullah's centralising policies and social reforms, which were viewed as government intrusions into their traditional areas of influence. ${ }^{75}$ For instance, the centralisation and secularisation of the judicial system threatened a significant source of income for religious officials, who were paid to settle disputes and other local legal issues. ${ }^{76}$ The constitution and laws promulgated by Amanullah also posed a threat to the ulema's influence and power, which were derived from their role in defining and interpreting religious laws.

More importantly, Amanullah failed to exercise the level of control over the ulema that his predecessors had, even though his modernisation program was a greater threat to the power of the ulema than anything done before. Preceding monarchs understood the necessity of forcing the ulema into submission, and did not hesitate from using force to achieve this. Abdul Rahman threatened mullahs who opposed him with either exile or a departure 'into the next world', while Habibullah promptly executed mullahs who publicly opposed his visit to India at the invitation of the British. ${ }^{77}$ Instead of coercing or co-opting the ulema into submission earlier in his reign while he still possessed sufficient political capital, Amanullah did nothing until he was confronted by open rebellion.

In his bid to modernise Afghanistan, Amanullah systematically undermined the power and prerogatives of the traditional power holders in the country, without addressing their concerns or making any concessions in return. Filled with resentment, local ulema and tribal leaders forged a marriage of convenience,

72 Gregorian, Emergence of Modern Afghanistan, 271-72; Poullada, Reform and Rebellion, 108.

73 ibid., 109.

74 Amanullah was even once considered as a possible successor to the former Ottoman Caliphate. See Overby, Hard Case of Reform, 13; Gregorian, Emergence of Modern Afghanistan, 261-62.

75 Astri Suhrkei and Kaja Borchgrevink, 'Negotiating Justice Sector Reform in Afghanistan', Crime, Law and Social Change 51, No. 2 (2008), 216.

76 Poullada, Reform and Rebellion, 120

77 Shahrani, 'Afghanistan's Failed Nation-building Project', 665-66. 
which first reared its head in 1924, when Mullah Abdullah, aka the Lame Mullah, succeeded in inciting the Mangal and Jadran tribes in Khost to rebel in a conflict that eventually cost 14,000 lives. ${ }^{78}$ To deal with the crisis, Amanullah called for a national assembly (loya jirgah) of prominent ulema and tribal leaders and, in exchange for their support against the rebellion and its participants, he was forced to make concessions, such as abolishing restrictions on polygamy and restoring the power of religious judges. ${ }^{79}$

While much attention has been given to the reforms that Amanullah was forced to sacrifice at the loya jirgah of 1924, with Senzil Nawid going as far as to consider it a 'decisive victory' for the ulema, there has been less focus on what Amanullah was allowed to retain. ${ }^{80}$ The bulk of Amanullah's reforms in the fields of administration, education, taxation and conscription remained intact. While the tribal leaders and ulema would certainly have preferred having no reforms at all, it is clear that they were willing to compromise so long as their interests were safeguarded. Amanullah refused to acknowledge this, however, and after his European tour of 1928, he increased the pace and scope of his reforms. ${ }^{81}$ Instead of seeking the ulema's cooperation, Amanullah publicly derided them as 'corrupt' and 'narrow-minded', ending their state stipends and forcing religious officials to be trained in state-sponsored schools. ${ }^{82}$ The final straw came during the loya jirgah of 1928, when Amanullah humiliated tribal and religious leaders by forcing them to wear European clothes. ${ }^{83}$ When a tribal revolt developed in Jalalabad in 1928, it had the full support of the ulema, who labelled Amanullah as an infidel. ${ }^{84}$ Amanullah tried to pacify his opponents by repealing several contentious social and religious reforms, but it was too late. He abdicated the throne in January $1929 .{ }^{85}$

\section{Alienating the Army}

Although Amanullah angered ordinary Afghans and the tribal and religious leaders, he might still have been able to salvage his rule and reforms had he retained support from the most important institution of all, the army. As the

\footnotetext{
78 Saikal, Modern Afghanistan, 81; Shahrani, 'Afghanistan's Failed Nation-building Project', 670.

79 Barfield, Cultural and Political History, 186.

80 Senzil Nawid, 'The Khost Rebellion: The Reaction of Afghan Clerical and Tribal Forces to Social Change', Review of the Department of Asian Studies and the Department of Studies and Research on Africa and Arab Countries 56, No. 3 (1996), 316.

81 Amanullah's trip to Europe was a clear contribution to his sheer insistence on modernisation, despite facing resistance. He noted that 'Paris filled me with joy, Berlin astounded me, London caught my imagination, but it was my homeland which ignited fire in me'. See Shahrani, 'Afghanistan's Failed Nation-building Project', 671.

82 ibid.; Barfield, Cultural and Political History, 189.

83 Emadi, Repression, Resistance and Women, 64.

84 Ewans, A Short History, 95.

85 Roberts, The Origins of Conflict, 44.
} 
revolts that toppled his rule were largely localised in the Pashtun-occupied areas of the country, an effective and loyal army should have been able to suppress them. ${ }^{86}$ The army had long been essential in bolstering the rule of Amanullah's predecessors, and it was through the army's support that Amanullah had succeeded in seizing the throne after the death of his father. ${ }^{87}$ When Amanullah met Ataturk in Turkey, he was warned that the success of his modernisation program depended on the support of a strong army to suppress resistance. ${ }^{88}$ Instead, Amanullah's army failed in both the Khost Rebellion of 1924, where only tribal intervention saved the day, and the final rebellion in $1928 .^{89}$

While Amanullah did institute reforms that were intended to create an effective and loyal army, his negligence in implementing the reforms 'functionally dismantled and ultimately destroyed' the military. ${ }^{90}$ The decision to purge the army of its veterans in order to build a professional standing force was not followed up with adequate training, resulting in an inexperienced army that was inferior to its predecessor. ${ }^{91}$ Improved benefits such as food and housing, which were intended to compensate for pay cuts, fell by the wayside due to administrative delays and corruption. ${ }^{92}$ This resulted in a loss of morale and professionalism, as soldiers had to accept other employment to support themselves. ${ }^{93}$ Amanullah's support for foreign military instructors from Turkey also served to alienate soldiers and officers who prided themselves on a militaristic tribal culture and were insulted at having to learn warfare from foreigners. ${ }^{94}$ Amanullah's military reforms caused recruitment problems and mass desertions, with the army shrinking from over 60,000 men during the time of Abdur Rahman to just 11,000 by $1928 .{ }^{95}$ Not only was the small and inexperienced army incapable of dealing with the tribal uprisings, but Amanullah had also alienated the army to such an extent that masses of soldiers simply defected to the rebels. ${ }^{96}$

Poullada defends Amanullah's impact on the military, stating that he made a laudable effort in reforming it, but 'success eluded him' ${ }^{97}$ But the army's failure during the Khost Rebellion should have signalled to Amanullah that it was imperative to revise his military program. Amanullah did not listen to advice from his minister of war, Nadir Shah, who warned him about the importance of

\footnotetext{
Shahrani, 'Afghanistan's Failed Nation-building Project', 664.

Roberts, The Origins of Conflict, 40.

Rasanayagam, A Modern History, 21.

Barfield, Cultural and Political History, 187.

Dessasso, Development of Afghanistan National Stability, 25.

Poullada, Reform and Rebellion, 118.

ibid., 117.

Saikal, Modern Afghanistan, 78.

Shahrani, 'Afghanistan's Failed Nation-building Project', 669.

Ali A Jalali, Rebuilding Afghanistan's National Army (Carlisle: US Army War College, 2002), 77.

Overby, Hard Case of Reform, 18-19.

Poullada, Reform and Rebellion, 118.
} 
the army. ${ }^{98}$ Ironically, Amanullah's negligence in maintaining the military came from his belief that he would always be able to muster the tribes to deal with military threats. ${ }^{99}$ As he discovered in 1929, this was not necessarily the case.

\section{Conclusion}

Many observers have concluded that the current nation-building effort in Afghanistan is doomed to failure, and have even referred to Amanullah's failed modernisation effort to demonstrate the futility of such a task. ${ }^{100}$ While Amanullah's program was flawed, however, his experiences do not suggest that such a task is impossible. After all, Amanullah's reign lasted for a decade, despite increasing hostility towards his reforms. Amanullah was able to secure some measure of support from tribal and religious leaders, even in times of crisis, such as the Khost Rebellion. Unfortunately, Amanullah's firm belief in the necessity and benefits of modernisation blinded him to the offense and economic hardship that his reforms wreaked on the people and the extent of power and benefits that the tribal leaders and ulema stood to lose in a modernised Afghanistan. More importantly, Amanullah failed to acknowledge that the support of a strong and loyal army was necessary to protect himself from resistance to his reforms. If the modernisation program had been better managed, taking cultural, tribal and religious sensitivities into account, both Amanullah's rule and his reforms may have continued. Amanullah failed to do this, however, and his reign and his reforms came to an end in 1929.

\section{Bibiliography}

Ahmad, ND. The Survival of Afghanistan, 1747-1979. Lahore: Institute of Islamic Culture, 1990.

Barfield, Thomas. Afghanistan: A Cultural and Political History. Princeton, NJ: Princeton University Press, 2010.

Baynard, Sally Ann. 'Historical Setting'. In Afghanistan, A Country Study, edited by Richard F Nyrop \& Donald M Seekins. Washington, DC Foreign Area Studies, The American University, 1986.

\footnotetext{
98 Baynard, 'Historical Setting', 42-46.

99 In July 1923, Amanullah told the people, 'These are the days of the pen, not of the sword ... therefore send your sons to school. Our martial qualities are sufficient, it is education that we lack.' See Jalali, Rebuilding Afghanistan's National Army, 86.

100 Andrew Wilder and Stuart Gordon, 'Money Can't Buy America Love', Foreign Policy (2009). http:// www.foreignpolicy.com/articles/2009/12/01/money_cant_buy_america_love(accessed 02 October 2012).
} 
Burki, Shireen Khan. 'The Politics of Zan from Amanullah to Karzai'. In Land of the Unconquerable: The Lives of Contemporary Afghan Women, edited by Jennifer Heath and Ashraf Zahedi. Berkeley and Los Angeles: University of California Press, 2011.

Christensen, Asger. Aiding Afghanistan: The Background and Prospects for Reconstruction in a Fragmented Society. Copenhagen: NIAS Publishing, 1995.

Dessaso, Christopher D. Toward Development of Afghanistan National Stability: Analyses in Historical, Military and Cultural Contexts. Kansas: School of Advanced Military Studies, United States Army Command and General Staff College, 2010.

Dupree, Louis. 'Afghanistan, 1880-1973'. In Commoners, Climbers and Notables, edited by CAO Nieuwenhuijze. Leiden: EJ Brill, 1977.

Emadi, Hafizullah. Repression, Resistance and Women in Afghanistan. Westport CT: Praeger, 2002.

Ewans, Martin. Afghanistan: A Short History of its People and Politics. New York: HarperCollins, 2002.

Felbab-Brown, Vanda. Afghanistan Ten Years after 9/11: Counterterrorism Accomplishments while a Civil War is Lurking? Brookings Institute (2011). http://www.brookings.edu/research/opinions/2011/09/06-afghanistanfelbabbrown (accessed 1 October 2012).

Gregorian, Vartan. 'Mahmud Tarzi and Saraj-ol-Akhbar: Ideology of Nationalism and Modernization in Afghanistan.' Middle East Journal 21, No. 3 (1967): 345-68.

- The Emergence of Modern Afghanistan. Stanford: Stanford University Press, 1969.

Jalali, Ali A. Rebuilding Afghanistan's National Army. Carlisle: US Army War College, 2002.

Malik, Aqab M. The Modernisation Process in Afghanistan - A Retrospective. Islamabad: Institute of Security Studies Islamabad, 2012.

Nawid, Senzil. 'The Khost Rebellion: The Reaction of Afghan Clerical and Tribal Forces to Social Change'. Review of the Department of Asian Studies and the Department of Studies and Research on Africa and Arab Countries 56, No. 3 (1996): 311-19.

Olesen, Asta. Islam and Politics in Afghanistan. Richmond: Curzon Press, 1995. 
Poullada, Leon B. Reform and Rebellion in Afghanistan, 1919-1929. Ithaca and London: Cornell University Press, 1973.

Overby, Paul. Amanullah: The Hard Case of Reform in Afghanistan. Occasional Paper 31. New York: The Afghanistan Forum, 1992.

Rasanayagam, Angelo. Afghanistan: A Modern History. London: IB Tauris, 2003.

Roberts, Jeffery J. The Origins of Conflict in Afghanistan. Westport, CT; London: Praeger.

Saikal, Amin. Modern Afghanistan, A History of Struggle and Survival. London and New York: IB Tauris, 2004.

Shahrani, M Nazif. 'King Aman-Allah of Afghanistan's Failed Nation-building Project and its Aftermath'. Iranian Studies 38, No. 4 (2005): 661-75.

Suhrke, Astri and Borchgrevink, Kaja. 'Negotiating Justice Sector Reform in Afghanistan'. Crime, Law and Social Change 51, No. 2 (2008): 211-30.

Tomsen, Peter. The Wars of Afghanistan. New York: Public Affairs, 2011.

Weber, Max. 'Politics as a Vocation'. In Max Weber: Essays in Sociology, edited by HH Gerth. London: Routledge, 1948.

Wilder, Andrew and Gordon, Stuart. 'Money Can't Buy America Love'. Foreign Policy (2009). http://www.foreignpolicy.com/articles/2009/12/01/money_ cant_buy_america_love(accessed 02 October 2012).

Zapf, Wolfgang. Modernization Theory - And the Non-western World. Emeriti Projekte: Wissenschaftszentrum Berlin für Sozialforschung, 2004. 
This text taken from The ANU Undergraduate Research Journal Volume Five 2013, published 2014 by ANU Press, The Australian National University, Canberra, Australia. 